Anna Nosek

Uniwersytet w Biatymstoku

\title{
Matka Boża Dziewica w poezji Młodej Polski
}

\section{THE BLESSED VIRGIN MARY IN YOUNG POLAND POETRY}

The article analyses the motifs of the Virginity and the Annunciation of the Virgin Mary in Young Poland poetry. They appear in the writings of many poets, i.e. Maria Konopnicka, Leopold Staff, Jan Kasprowicz, Bronisława Ostrowska, Kazimiera Zawistowska, Józef Ruffer and others. The interest in the Motherhood of God in this period stemmed mostly from a general increase in religiousness but it also had its national and patriotic roots. The expansiveness of the motifs of Virginity and the Annunciation of St. Mary after 1900 was also connected with the $50^{\text {th }}$ anniversary commemoration of the announcement of the doctrine of the Immaculate Conception. The changes in the world-view in the era initialized by vitalism, the fascination with spirituality, broad-sense purity, folk nature and the Franciscan philosophical trend were also significant for the poetic presentation of St. Mary.

Key words: Blessed Virgin Mary, Annunciation, motif of the virginity of the Blessed Mary in literature, Young Poland poetry.

Pojawiające się często w poezji Młodej Polski obrazy Maryi Panny oraz Zwiastowania świadczyły o ich ważności dla pokolenia przełomu XIX i XX wieku. W epoce tej zainteresowanie macierzyństwem Boskim wynikało z ogólnego wzrostu religijności, ale też ze względów narodowych i patriotycznych. Równie popularny był bowiem wówczas w poezji wizerunek Matki Bożej jako opiekunki i Królowej Polski, ale też Matki Bożej Bolesnej. Ekspansywność motywów dziewiczości Maryi oraz Zwiastowania po 1900 roku wiązała się także z obchodami 
50-lecia ogłoszenia dogmatu o (w 1904 r.). Maria Jasińska, badając i analizując utwory poetyckie poświęcone Matce Bożej do 1918 roku, słusznie stwierdziła, iż na początku XX wieku powstało paradoksalnie wiele utworów dotyczących czystości Maryi, mających charakter pochwalny oraz dziękczynny. Świadczyć to mogło o ówczesnym powszechnym przeświadczeniu o bliskości, komplementarności tych dwóch maryjnych dogmatów - Niepokalanego Poczęcia i dziewictwa. Powołując się na książkę Jeana Guittona pt. Maryja, badaczka zwracała jednak również uwagę na zjawisko prawdopodobnego pomieszania, niezrozumienia teologicznego znaczenia odnoszących się do Matki Bożej terminów ${ }^{1}$.

Motywy dziewictwa Maryi oraz Zwiastowania znaleźć można w poezji takich młodopolskich twórców, jak: Leopold Staff (Matka Jagodna, Zwiastowanie), Jan Kasprowicz (Salve Regina), Bronisława Ostrowska (np. Przedwiośnie, Immaculata), Kazimiera Zawistowska (Zwiastowanie, Przenajświętsza, Godzinki), Władysław Orkan (Niepokalana), Józef Ruffer (Maryja Panna), Włodzimierz Perzyński (Anioł Pański), Wacław Wolski (Zwiastowanie, Sen, Śnieg), Lucjan Rydel (W maju), Zygmunt Różycki (Z niebieskich widzeń), Maria Grossek-Korycka (Litania dziękczynna, Modlitwa), Anna Zahorska (Zwiastowanie), Edward Słoński [Na biate lilie...] oraz wielu innych². Najświętszą Maryję Pannę, Niepokalaną przywoływał kilkakrotnie w swych dramatach również Stanisław Wyspiański (wymienić można Legion, Akropolis, fragment obrazu dramatycznego Królowa Polskiej Korony).

Duża część młodopolskich utworów poetyckich, w których występuje Matka Boża Dziewica, ma charakter dziękczynny³. Można je traktować jako swoiste akty wiary i uwielbienia, połączone z przywoływaniem i kontemplacją przymiotów Maryi oraz tworzeniem religijnego nastroju. Utwory tego typu ograniczały elementy refleksyjne, nie było w nich również śladu dociekań filozoficznych, rozumowych ${ }^{4}$.

1 Zob. M. Jasińska, Matka Boska w poezji poromantycznej (do r. 1918), [w:] Matka Boska w poezji polskiej: szkice o dziejach motywu, t. 1, oprac. M. Jasińska, Z. Jastrzębski i in., Lublin 1959, s. 135.

$2 \quad$ Zob. Niebios iziemi królowa. Najświętsza Maryja Panna w poezji polskiej, zebrał i wstępem opatrzył E. Wolski, Włocławek 1914.

$3 \quad$ Zdaniem niektórych badaczy taki typ twórczości niwelował podmiotowość w doświadczeniu religijnym oraz miał predylekcję do idealizacji i konwencjonalizacji. Por. H. Filipkowska, Poezja religijna Młodej Polski, [w:] S. Sawicki, P. Nowaczyński (red.), Polska liryka religijna, Lublin 1983, s. 309.

$4 \quad$ Klasycznym i wysoko cenionym przez badaczy wierszem reprezentującym ten młodopolski nurt poezji jest Maryja Panna J. Ruffera. Maria Jasińska uznała go za doskonały przykład i manifestację fideizmu. Zob. M. Jasińska, Matka 
Bardzo ważne w maryjnej liryce pochwalnej okazywały się barwy, symbolizujące czystość, przede wszystkim liczne „odcienie” bieli, ale też srebra, złota. Niejednokrotnie poeci podkreślali „słoneczność”, jasność, promienność, gwieździstość i wertykalność Maryi Panny, niekiedy w stopniu najwyższym. „Przejasną świecisz glorią, / promienna, gwiazdolica, / w łunach Twoja wieżyca"5 - tak wielbi Maryję Chór w Akropolis Stanisława Wyspiańskiego.

Artyści młodopolscy podkreślali też poprzez liczne epitety i wyliczenia nieskazitelność samej czystości Maryi. W wierszu Ruffera Maryja Panna czytamy, iż Matka Boża ,jaśnieje czystością słodką, nienaganną" 6 . W przywoływanym już dramacie Akropolis Wyspiańskiego, ale też $\mathrm{w}$ wielu innych utworach z tego okresu, Matka Boża jest porównywana do lilii jako symbolu czystości, niewinności, świętości lub kwiat ten stanowi synonim Maryi ${ }^{7}$. Bardzo często poeci młodopolscy posługiwali się też aurą słoneczności, bieli, anielskości, która wzmacniała, poprzez liczne powtórzenia, przeświadczenie o niedościgłej świętości i czystości czczonej Matki Bożej. Przykładowo wiersz Przenajświętsza Kazimiery Zawistowskiej zaczyna się następująco: „O wizjo! Biała wizjo! O białe konwoje/ Archaniołów, niosących w słodkiej kantylenie, / Swojej Pani dostojnej, korne pozdrowienie!..."

Niezliczona wydaje się również liczba różnego rodzaju synonimów i określeń Maryi Panny, mających charakter podniosły, dziękczynny, które rozsiane są w wierszach dotyczących Zwiastowania i Jej dziewictwa. Niektóre z nich mają bardziej tradycyjny charakter (Niepokalana, Królowa, Pani świata), są też zapożyczane z maryjnych modlitw, np. z Litanii Loretańskiej, a następnie poetycko modyfikowane (Litania dziękczynna M. Grossek-Koryckiej). Młodopolskie synonimy Matki

Boska..., op. cit., s. 136. Równie wysoko ocenia ten utwór D. Trześniowski w swej rozprawie Biblijne twarze i maski. Młodopolski portret kobiety, [w:] E. Łoch (red.), Modernizm i feminizm. Postacie kobiece $w$ literaturze polskiej o obcej, Lublin 2001, s. 150.

$5 \quad$ S. Wyspiański, Akropolis, fragm. przedr. [w:] Matka Boska w poezji polskiej. Antologia, t. 2, Lublin 1959, s. 141.

6 J. Ruffer, Maryja Panna, [w:] idem, Wybór poezji, wybór i oprac. M. Wyka, Kraków 1985, s. 104.

7 O asocjacjach lilii i Matki Bożej w literaturze i kulturze, a także licznych ikonograficznych, pieśniowych i poetyckich przykładach w odniesieniu do poezji Młodej Polski pisała B. Kuryłowicz. Zwracała przy tym uwagę na „trwałość i stabilność omawianego fragmentu modelu pojęciowego słowa", zob. B. Kuryłowicz, Semantyka nazw kwiatów w poezji Młodej Polski, Białystok 2012, s. 135.

$8 \quad$ K. Zawistowska, Przenajświętsza, [w:] eadem, Utwory zebrane, Kraków 1982, s. 132. 
Dziewicy zadziwiają swym kunsztem poetyckich tropów, metafor, porównań, epitetów, jeszcze inne wskazują na synkretyzm kulturowy epoki (np. Maryja jako Pani słoneczna). Wiele z nich ma natomiast charakter bezpośredniego zwrotu, pochwalnej apostrofy do czczonej, obdarzanej miłością Adresatki. Wymieńmy choć kilka przykładów: „Biała, czysta lilio, o Przenajświętsza Panno”9; „Pani słoneczna, / Niepokalana, Ty wieczna" ${ }^{10}$; „Zdrowaś Maryjo! Owoc żywota, ty jako arka poniesiesz złota, / By z dziewiczego wykwitła łona, Ożywcza słodycz winnego grona!...”"11, „O rajskich łąk wiosno bez końca / Na kuli świata stojąca (...), O gwiazdo morza, / Jutrzenna zorza (...), Lustro Przedwiecznego Oblicza, / Matko dziewicza!"12.

Kolejnymi charakterystycznymi zabiegami, towarzyszącymi młodopolskim poetyckim prezentacjom wątków dziewictwa Maryi i Zwiastowania są połączenia synestezyjne, ale też gromadzenie czy uruchamianie licznych wrażeń sensualnych: zmysłu słuchu (za pomocą onomatopei, a zwłaszcza stałego w wielu tekstach motywu bicia dzwonu na Anioł Pański, szumu kwiatów i zbóż) ${ }^{13}$, zmysłu wzroku (czemu służy gromadzenie odpowiedniej kolorystyki, kojarzonej z czystością, świętością), a nawet - powonienia. W młodopolskich wierszach maryjnych czuć słodki zapach łąk, pól, dojrzewających winorośli, kwitnących sadów i kwiatów, zwłaszcza róż (Anioł Pański W. Perzyńskiego), „srebrzystych lilii i białych stokroci” (Z niebieskich widzeń Z. Różyckiego), bzu - w jednym z wierszy czytamy, że na cześć Maryi Panny „bzy się kołyszą słodką wonią"14.

W wielu kreacjach Matki Bożej Dziewicy z okresu Młodej Polski uwidaczniają się tendencje idealizujące, niekiedy też sentymentalne ${ }^{15}$,

$9 \quad$ S. Wyspiański, Akropolis, op. cit., s. 141.

$10 \quad$ Idem, Legion, op. cit., s. 140.

11 K. Zawistowska, Zwiastowanie, op. cit., s. 130.

12 M. Grossek-Korycka, Litania dziękczynna, przedr. [w:] Matka Boska w poezji polskiej, t. 2, op. cit., s. 137.

13 Motyw bicia dzwonu na Anioł Pański jest charakterystyczny nie tylko w młodopolskiej liryce maryjnej, ale pojawia się też w tekstach tzw. pseudomaryjnych lub zupełnie świeckich, w których pełni często funkcję ornamentu dźwiękowego, potęguje odpowiedni nastrój (nawet dekadencki nastrój znużenia i zwątpienia, jak np. w znanym wierszu Anioł Pański Kazimierza Przerwy-Tetmajera).

14 A. Zahorska, Zwiastowanie, [w:] eadem, Dniom zmartwychwstania, Wilno 1921, s. 66 .

15 M. Jasińska zwracała uwagę, że taki sentymentalny wizerunek Maryi spopularyzował w poezji, ale też pieśni religijnej na przełomie XIX i XX wieku ks. Karol Antoniewicz. Na wzór Pieśni majowej [Chwalcie łacki umajone] powstawało wówczas bardzo dużo innych utworów. Eadem, op. cit., s. 130-131. 
świadczące m.in. o dużej religijności maryjnej pokolenia przełomów wieków ${ }^{16}$ i czułym, bliskim, „dziecięcym” niejako stosunku do religijnego adresata utworów, ale też pozytywnej waloryzacji kobiecości w jej wymiarze macierzyńskim. Kobieta-matka, jak dowodziłam w swej książce „Matko! Jak wiele masz twarzy?...” bardzo rzadko podlegała pejoratywnym ocenom i ujęciom w poezji tego okresu (w przeciwieństwie do prozy i dramatu), częściej za to artyści pokazywali wartość, piękno i świętość maternitas ${ }^{17}$. Maryja zaś na przełomie XIX i XX wieku wciąż jeszcze stanowiła niekwestionowany wzorzec kobiecości. W odniesieniu do Młodej Polski można - w wielu wypadkach - powtórzyć to, co Jarosław Ławski pisał o wyobrażeniach kobiecości w XIX wieku: „Fundamentalną rolę w zabiegach «idealizacyjnych», w przywoływaniu rozmaitych wizji kobiecości odegrała w XIX w. silnie, wyraziście się objawiająca «maryjność» kultury polskiej"18.

Warto podkreślić, że w poezji początku XX wieku popularność motywu dziewictwa Maryi posiada też, oprócz religijnych, inne motywacje, wpisane w specyfikę epoki. Łączy się z tendencjami tzw. witalistycznymi oraz ludowością ${ }^{19}$, ale też koresponduje $\mathrm{z}$ modernistycznymi ideałami i poszukiwaniami, widocznymi także w literaturze początku XX wieku: zwłaszcza czystości, duchowości, bezcielesności ${ }^{20}$. Wątek

16 Pisała o tym $m$ in. B. Olech w swej książce Harmonia, liryzm, trwoga. Studia o twórczości Bronisławy Ostrowskiej, Białystok 2012, s. 62.

17 Zob.A. Nosek, ,Matko! Jak wiele masz twarzy?”. Młodopolskie wiersze o kobiecie $w$ roli matki $i$ doświadczeniu macierzyństwa, Białystok 2014.

18 J. Ławski, Marie romantyków. Metafizyczne wizje kobiecości: Mickiewicz-Malczewski - Krasiński, Białystok 2003, s. 713. Zob. również A. Węgrzyniakowa, Matka $w$ poezji kobiet, [w:] G. Szewczyk (red.), Postać matki w niemieckiej i polskiej literaturze XIX $i$ XX wieku, Katowice 1995, s. 51.

19 Na temat tendencji witalistyczno-odrodzeńczych, jakie pojawiły się po 1900 w poezji młodopolskiej pisała M. Podraza-Kwiatkowska w swym studium Pustka - otchłań - petnia. (Ze studiów nad młodopolska symbolika inercji i odrodzenia), [w:] M. Podraza-Kwiatkowska (red.), Młodopolski świat wyobraźni. Studia i eseje, Kraków 1977; A. Nosek, Matka Boża w kontekście mtodopolskiej ludowości i witalizmu. „Panagia” Kazimiery Zawistowskiej, [w:] D. Kulesza, M. Lul, M. Sawicka (red.), Bóg artystów XX wieku, Białystok 2003, s. 155-161.

20 O młodopolskimideale czystości zob.tekst M.Podrazy-Kwiatkowskiej, Kompleks Parsifala.O młodopolskimideale czystości, [w:] eadem, Wolności transcendencja, Kraków 2001. Por. też M. Stala, Pejzaż człowieka. Młodopolskie myśli i wyobrażenia o duszy, duchu i ciele, Kraków 1994. Nie można oczywiście zapomnieć o ogólnoeuropejskiej problematyce i ideologii modernizmu katolickiego, która wywarła wpływ również na wielu twórców młodopolskich.Zob. T. Lewandowski, Mtodopolskie spotkania z modernizmem katolickim, [w:] S. Fita (red.), Problematyka religijna wliteraturze pozytywizmui MłodejPolski.Ś wiadectwa poszukiwań, Lublin 1993, s. 197-252. Zob. też W. Gutowski, Wyobraźnia religijna czy religia 
Dziewiczego Poczęcia Chrystusa włączyć można zatem w szereg symboli eksplikujących młodopolskie pragnienie „świata duchowego”, nieskażonego materią. Pozytywna waloryzacja czystości i świętości Maryi wyrażać by mogła szersze, światopoglądowe przemiany zachodzące w ramach epoki albo może charakterystyczną dla niej opozycję między dążeniem do pełni (tzw. mit chuci) a samoograniczeniem, ascezą pragnieniem „czystości”. Motyw dziewictwa Matki Bożej występuje bowiem często w poezji po 1900 roku w sąsiedztwie lub jest skontrastowany z obrazami upodlenia, grzeszności i nędzy ludzkości, szukającej w Maryi ratunku. Tak jest np. w Salve Regina Jana Kasprowicza, Godzinkach Kazimiery Zawistowskiej. W utworach stylizowanych na kościelne pieśni błagalne czy wykorzystujących poetykę ekspresjonistyczną i katastroficzną motyw czystości Maryi wskazuje na istotne przesunięcia w młodopolskim światopoglądzie. Wyraża modernistyczne pragnienie przezwyciężania stanu dekadencji, upadku m.in. poprzez zwrot, przywoływanie symboli czy postaci mitycznych bądź religijnych, ewokujących pozytywne wartości. Podobnie sądzi Maria Jasińska, pisząc o Salve Regina Kasprowicza:

Głębokie znaczenie ma czystość Panny nad pannami w hymnie Kasprowicza Salve Regina. Przeciwstawiana kilkakrotnie obrazom upodlenia, nędzy i bólu staje się dla ludzkości przedmiotem najgłębszej tęsknoty i symbolem jej zwycięstwa nad otchłanią zatracenia. (...). Na neoromantyczny kult dziewictwa i czystości Maryi można spojrzeć właśnie poprzez właściwe tej epoce zanurzenie w katastrofizm, satanizm, przerażenie złem ${ }^{21}$.

Ciekawe, inspirowane młodopolskim witalizmem interpretacje dogmatu dziewictwa Maryi oraz motywu Zwiastowania wyszły spod pióra Bronisławy Ostrowskiej. W wierszu Przedwiośnie poetka ta, podobnie jak np. Staff w pięknym liryku Matka Jagodna, subtelnie wskazywała, że Maryja Panna swą czystością przemienia cały stworzony świat, $\mathrm{w}$ tym wszelkie procesy związane $\mathrm{z}$ rodzeniem się nowego życia. Akt Zwiastowania Matce Bożej powiązany został w Przedwiośniu z wiosennym procesem wegetacji. W wierszu czytamy: „Nad obudzonej ziemi łonem / Dzwon bije głośno, bezustannie / W powietrzu

wyobraźni? Dylemat (nie tylko) młodopolski, [w:] E. Paczoska, J. Sztachelska (red.), Literatura Młodej Polski. Między XIX a XX wiekiem, Białystok 1998.

$21 \quad$ M. Jasińska, Matka Boska..., op. cit., s. 133-134. Warto zwrócić uwagę, że w Salve Regina Matka Boża to równocześnie patronka wiosny, procesów wegetacyjnych. Dodatkowo w maryjny obraz białej lilii, symbolizujący czystość, wyposażona jest zantropomorfizowana tęsknota, jak również dusza. 
wiosną zbłękitnionem / Anioł zwiastował Marii Pannie!”22. Zabieg taki usankcjonowany jest oczywiście młodopolskim naturocentryzmem i witalizmem, ale też fascynacją samej Ostrowskiej ewangelicznymi wartościami, sferą duchową oraz biologiczną, postrzeganą jako fenomen uczestniczenia w sacrum. W powyższym fragmencie wskazuje na to chwyt antropomorfizacji ziemi, mającej atrybuty kobiety (epitet „łono ziemi”) oraz przenikanie się elementów rzeczywistości ze zdarzeniami biblijnymi, które dzięki temu nabierają konkretności, stają się namacalne. Do Zwiastowania dochodzi bowiem w konkretnej, przyrodniczej przestrzeni. Czas biblijny zostaje w Przedwiośniu zastąpiony czasem biologicznym, powtarzalnym (przedwiośniem). Elementem łączącym różne rodzaje czasu oraz pozwalającym na poetycką analogię i wytłumaczenie paradoksu chrześcijańskiego dogmatu jest w wierszu Ostrowskiej dziewictwo. Należy je przy tym rozumieć nie tylko jako stan czystości w odniesieniu do człowieka (kobiety), ale też piękna, nieskazitelności, świeżości budzącej się do życia natury, stan oczekiwania na macierzyństwo. W utworze mowa bowiem o „dziewiczości” wczesnej wiosny i Boskiego Poczęcia: „w cudu dziewiczych snów godzinie / Anioł zwiastował Pannie Marii”"23. W Przedwiośniu Ostrowskiej uwagę zwraca charakterystyczna aura nastrojowo-emocjonalna, współtworząca klimat dziewiczości. Buduje ją poetka przede wszystkim przez połączenia synestezyjne, np. „w powietrzu wiosną zbłękitnionem; w jasności cichej i radosnej, / Topi się złotych wierzb pąkowie", ciepłe, słoneczne kolory (złoty i błękitny) oraz sielankowe sytuacje (aniołowie szukający kwiatów wiosny). Jedność nastroju i kolorytu sugeruje zatem identyczność lub analogiczność opisywanych zdarzeń: wiosennego zainicjowania wegetacji i Zwiastowania. Radosnego nastroju przedwiośnia i Boskiego Poczęcia nie zakłóca nawet w świetle utworu Ostrowskiej „zwid Kalwarii”, który pojawia się także w innych młodopolskich lirykach dotyczących Zwiastowania (np. Konopnickiej, Staffa).

22 B. Ostrowska, Przedwiośnie, [w:] eadem, Poezje wybrane, oprac. A. Wydrycka, Kraków 1999, s. 77.

$23 \quad$ M. Januszewicz zwraca uwagę na duże zainteresowanie formacji modernistycznej problematyką dziewiczości, traktowanej jako wartość i popularyzowanej m.in. przez prerafaelitów: „Kobiety prerafaelitów uosabiały piękno, czystość, niewinność, czyli wszystko, co żywotne w malarstwie naszego kręgu kulturowego, począwszy od średniowiecza i co w ikonografii chrześcijańskiej związane było z postacią Matki Boskiej”. M. Januszewicz, Malowany dramat. Ozwiązkach literatury $z$ malarstwem $w$ „Weselu” Stanistawa Wyspiańskiego, Zielona Góra 1994, s. 22. 
Takie przedstawienie Zwiastowania wpisuje się jednocześnie w młodopolską regułę modelowania sytuacji odrodzenia i związanego z nim dogmatu Zmartwychwstania. Zdaniem Wojciecha Gutowskiego „,́́wiadomości religijnej epoki obca była prawda - coraz bardziej podkreślana w XX-wiecznej teologii - o wewnętrznej jedności zdarzeń męki i Zmartwychwstania" "24. W pierwszej fazie Młodej Polski twórcy eksponowali zazwyczaj tę pierwszą, ponieważ oddawała nastroje dekadenckie $^{25}$. Także dogmat Zmartwychwstania moderniści sytuowali zazwyczaj poza kontekstem rozumienia teologiczno-religijnego. Włączali go natomiast w ramach „nurtu odrodzeńczego” w wegetatywny cykl przyrody. Moc odrodzenia, Zmartwychwstania i innych, związanych z tworzeniem się nowego życia, zdarzeń biblijnych, np. Zwiastowania, przypisywali nie tylko Boskiej Opatrzności, ale i wiosennemu nawrotowi sił życiowych czy zantropomorfizowanej wiośnie ${ }^{26}$.

Ciekawe treści wydobywa Ostrowska z faktu Zwiastowania oraz dziewictwa Maryi w utworze Immaculata. W Przedwiośniu bowiem poetka snuła analogię między macierzyństwem Boskim a wiosenną wegetacją, wydobywając przede wszystkim radosny klimat i nastrój towarzyszący tworzeniu się nowego życia. W wierszu Immaculata mowa jest o konsekwencjach dziewictwa Maryi, skutkach Zwiastowania. Wskazuje się tu na fenomen połączenia przez Maryję w momencie Boskiego Poczęcia tego, co biologiczne, cielesne z tym, co duchowe i święte. Według Anny Wydryckiej: „Maryja pełna łaski przywołuje sferę wartości duchowych, istnienia materialne przemienia w wartości spirytualne, materię przemienia w ducha"27.

Przy czym Ostrowska nie przejmuje opozycji materia - duch, a posiłkując się ideami genezyjskimi, stylistyką i frazeologią Słowackiego (mowa tu o „wieczności z Ducha”, przemianie pieśni w światło) rozwija poprzez postać Maryi motyw „przeanielenia” przyrody. Zwiastowanie przynosi w związku z tym nie tylko zapowiedź wolności ducha (wyzwolenie od grzechu), ale przede wszystkim uduchowienie materii. Słusznie stwierdziła Anna Wydrycka w odniesieniu do tej części tryptyku Pieśń miłości: „W twórczości Ostrowskiej, podobnie jak w jednym z Listów św. Pawła, nie tylko człowiek, ale i całą natura potrzebuje

${ }_{24}$ W. Gutowski, Mit-Eros-Sacrum.Sytuacje młodopolskie, Bydgoszcz 1999, s. 214.

25 Ibidem, s. 214.

26 Ibidem, s. 213-217. Analogicznie motyw męki i śmierci Chrystusowej był często sytuowany przez młodopolskich twórców w aurze jesiennej, obumierającej przyrody. Ibidem, s. 217.

27 A. Wydrycka, ,...Rymów gałazeczki skrzydlate...”. W świecie poetyckim Bronistawy Ostrowskiej, Białystok 1998, s. 133. 
Odkupienia. Rozumie je Ostrowska jako nowy, duchowy wymiar istnienia, dostępny dzięki ofierze Chrystusa i pośrednictwu Maryi”"28.

Użycie innej niż w Przedwiośniu perspektywy - nie ziemskiej, lecz kosmicznej - nadaje Boskiemu Poczęciu jeszcze większą rangę. W wierszu Immaculata wskazuje się na globalny wymiar Zwiastowania, poprzez plastyczne obrazy przemiany nocy w światło, wychodzenia ziemi, przedmiotów spod władzy mroku i śmierci. Poczęcie się Chrystusa jest jednocześnie ponownym odrodzeniem kosmosu, jego otwarciem na sferę ducha. W wierszu Ostrowskiej czytamy: „A gdy zwiastował Maryi anioł, dziewosłąb Boży, / Tedy się noc nad ziemią stała podobna zorzy:/ Zdrowaś Maria. / (...) / Z przedmiotów cienie spadły zrzuconą szat żałobą: / Pan z Tobą".

Bardzo dużą rangę dziewiczego macierzyństwa Maryi podkreślają nie tylko opisywane w tekście Ostrowskiej jego skutki, ale też sama forma i stylistyka wiersza Immaculata wskazują na pochwalny, dziękczynny charakter wypowiedzi. Poetka w oryginalny sposób łączy i trawestuje różne rodzaje pochwalnych modlitw, takich jak: Zdrowaś Mario, Litania Loretańska, Pod Twoja Obronę, Anioł Pański. W utworze Ostrowskiej czytamy: „Schyliły się lilie do poświęconych rąk, / Zajękły ziemi trzewia, / I wszystko wokół śpiewa: / Orędownico! / Któraś jest tęsknot naszych przed Panem ofiarnicą, / Matko Dziewico! / Która wyzwalasz żywot czystości mocą wielką, / Pocieszycielko! (...) / Racz przyjąć serce ziemi przed tobą rozmodlone, / Pod Twą obronę!". W przywołanym fragmencie Maryja występuje nie tylko w tradycyjnych rolach Boskiej „orędownicy” czy opiekunki, ale też pełni funkcję królowej przyrody, na co wskazują obrazy zantropomorfizowanej natury modlącej się do Matki Bożej. Badacze zwracają jednak uwagę, że kreacja ta odbiega od młodopolskich sentymentalnych ujęć Maryi jako królowej przyrody $^{29}$. Motto utworu Immaculata wskazuje na Maryjny franciszkanizm - Maryja brata się, manifestuje swą równość z najmniejszym stworzeniem ${ }^{30}$. Stąd, oprócz utrwalonego w tradycji motywu lilii, pojawiają się polne powoje i róże: „Siostrzyczki moje, siostrzyczki, / Lilie polne, różyczki, / Upodobał mię Pan / (...) / Rodzeństwo drobne moje, / Ze ziemskich pól powoje, / Wijcie się w splot niebiański”. Warto zwrócić

$28 \quad$ A. Wydrycka, Między bios a zoé. Poetycka antropologia w liryce Młodej Polski. Interpretacje, Białystok 2012, s. 253-254.

$29 \quad$ Pisała o tym M. Jasińska w przywoływanej już rozprawie, ale teza taka pojawia się też w najnowszych rozprawach, np. w książce B. Olech, Harmonia, liryzm, trwoga, op. cit., s. 63.

30 Również A. Wydrycka sytuuje utwór Immaculata w kontekście franciszkanizmu, a zwłaszcza franciszkańskiej ideifraternitas., [w:] eadem, Między bios a zoé, op. cit., s. 252-255. 
uwagę na estetyczne motywacje cytowanego ujęcia Maryi i przyrody, na secesyjność obrazu - wertykalizm złagodzony został falistą linią wijących się powoi. Z drugiej strony czystość Maryi podczas Zwiastowania włącza Ją w całokształt stworzonej natury jako jej najwyższy stopień, a „cała przyroda wielbi [Maryję] jako swoje wypełnienie, swój najwyższy przejaw doskonałości, przez który odzyskuje zerwaną przez Ewę łączność ze Słowem" "31. W związku z tym to zantropomorfizowana natura: „nieme duszejki kwietne”, „motyle”, „ptak” modlą się do Niej o duchową wolność i czystość.

Prezentacja Matki Dziewicy w wierszu Immaculata Ostrowskiej jest na tle młodopolskiej liryki maryjnej niewątpliwie ciekawa. Włącza się w sposób interesujący w ważną wówczas problematykę czystości czy bezcielesności, ale też natury, materii, która dzięki Maryi zyskuje wymiar sakralny. Autorka ta, co niegdyś podkreślała Anna Wydrycka, bardzo subtelnie zindywidualizowała tematykę maryjną, włączając ją także w problematykę kobiecą. Ostrowska bowiem wyraźnie podkreślała w swych Rozmyślaniach, iż Maryja to cel wędrówki kobiecej duszy ${ }^{32}$.

\section{$* * *$}

Uwagę w młodopolskiej poezji z motywami Zwiastowania i dziewictwa Maryi zwracają również takie utwory, które łączą je z równie ważną w tej epoce problematyką śmierci, heroizmu, ofiary. Można zatem stwierdzić, iż częściowej „mortalizacji” (termin W. Gutowskiego) podlegały wątki chrystologiczne, ale też motywy dziewiczego macierzyństwa Maryi oraz Zwiastowania. Wbrew pozorom ten drugi zabieg spotkać było można nie tylko w poezji wczesnomodernistycznej, o zabarwieniu dekadenckim, lecz również w tekstach późniejszych. W kręgu problematyki śmierci, ofiary, ale też heroizmu usytuowali tę tematykę m.in. Maria Konopnicka w wierszu Botticelli. Magnificat (z cyklu Madonna) oraz Leopold Staff w Zwiastowaniu. Wątek ten podjęła także Anna Zahorska, również w wierszu Zwiastowanie, gdzie cytowane słowa Maryi „Niech podług słowa mi się stanie!” 33 są świadomą zgodą na mękę swoją i Syna. Wymowne w tym względzie wydają się słowa kończące utwór: „Na Anioł Pański biją z wieży... / Pierś szczęściem bólu się rozszerzy...”34.

\footnotetext{
M. Jasińska, Matka Boska w poezji polskiej..., op. cit., s. 132.

B. Ostrowska, Rozmyślania, [w:] eadem, Utwory proza, Warszawa 1982, s. 57.

A. Zahorska, Zwiastowanie, op. cit., s. 68.

Ibidem, s. 68.
} 
Wiersz Botticelli. Magnificat to swoista, nowa interpretacja nie tylko wątku Zwiastowania, ale też biblijnego hymnu dziękczynnego Magnificat oraz przesłania obrazu włoskiego renesansowego malarza Sandra Botticellego, autora m.in. dzieła Madonna del Magnificat. Tradycyjne połączenie sceny Zwiastowania z koncepcją Maryi Radosnej przemienia się pod piórem Konopnickiej w kreację Matki Bożej Bolesnej, której „Bóg nadał rękoma obiema / Taki dział bólu, jakiego świat nie ma!" 35 . Nieobecny w biblijnej wersji Magnificat motyw Maryi cierpiącej, a nawet ukrzyżowanej („krzyż wbity w me łono”) ${ }^{36}$, ewokuje tragiczną wizję świata i człowieka (zwłaszcza kobiety w roli matki). Może też sugerować potęgę Boga, Boga karzącego, zsyłającego cierpienie. Konopnicka porównuje Go w tonacji ekspresjonistycznej do drapieżnego ptaka o ostrych szponach, który porywa Matkę Bożą ku Golgocie. Gdzie indziej wskazuje się karzącą moc Stwórcy, który „ku swej chwale i ku swej cześci / Z każdej łodygi miecz wywiódł boleści!”.

Konopnicka kojarzy Zwiastowanie nie tyle z dobrą nowiną, z zapowiedzią narodzin Chrystusa, ile z męką Golgoty, co potwierdza przywoływany motyw krzyża, ale też bezpośrednia wypowiedź Maryi, w której słowo „zwiastowanie” nie wiąże się z „oznajmieniem”, „wiadomością” o Boskim Poczęciu, lecz z zapowiedzią cierpienia: „A więc uwielbiaj, duszo moja, Pana... / Iż ci twa męka była zwiastowana".

W zwrotce trzeciej porównuje się Maryję do roli, ziemi niedającej plonów - staje się ona paradoksalnie symbolem śmierci, być może martyrologii narodu polskiego. Mowa tu bowiem nie o jednej, ale o wielu ,ziemiach mogilnych”:

A więc uwielbiaj duszo moja, Pana... / Ty - rola płonna, zorzami owiana, / Iż wspomniał, że me łono pustką leży, / I krzyż zasadził na mojej rubieży, / Iż ziem mogilnych uczynił mię niwą, / Łzami mnie obsiał i wziął ze mnie żniwo!.

Konopnicka wykorzystuje wątek Zwiastowania m.in. do dyskretnego zaznaczenia wielkości i ofiarności Matki Bożej, ale też każdej kobiety-matki. W istotę macierzyństwa wpisane jest bowiem nie tylko szczęście, ale przede wszystkim cierpienie, ból rodzenia, troska o dziecko i zgoda na jego śmierć (rozumiana też metaforycznie). $Z$ drugiej strony z wiersza Konopnickiej można wyczytać przesłanie, iż powierzona Maryi misja naznaczona wielkim cierpieniem to znak wywyższenia,

35 M. Konopnicka, Botticelli. Magnificat, [w:] eadem, Poezje, wyd. zupełne, krytyczne, t. 4, oprac. J. Czubek, Warszawa 1915, s. 123. Kolejne cytaty zgodnie $\mathrm{z}$ tym wydaniem.

$36 \quad$ Warto wskazać pośrednictwo Konopnickiej w prowokacyjnie profanującym wątek krzyża wierszu Próżnia S. Koraba-Brzozowskiego. 
Bożego błogosławieństwa. W takim kontekście przewijający się w wierszu wątek uwielbienia przez Nią Boga, zsyłającego cierpienie, może być poczytany jako świadectwo heroizmu i męstwa mówiącej w $M a-$ gnificat. Doświadcza Ona nadmiaru cierpienia nie tylko ze względu na swe Boskie Macierzyństwo. Godząc się na „mękę” ma świadomość tego, że jest to warunek odkupienia całej ludzkości. We fragmencie:

- A więc uwielbiaj duszo moja, Pana... / (...) / Odtąd wpatrzone w krzyż wbity w me łono, / Ludy nazwą mnie błogosławioną, / Iż służebnicę nawiedzić Pan raczył, / Serce jej przebił i mieczem naznaczył, / Iż błyszczy dotąd nad światem ta rana... / ...O magnificat!... Wielb, duszo ma, Pana!...

uwagę zwracają dodatkowo dwa obrazy: ukrzyżowanego łona i przebitego mieczem serca. Pierwszy obraz ilustruje cierpienie kobiety w roli matki, być może ból rodzenia graniczącego ze śmiercią. Motyw ukrzyżowanego łona bezpośrednio odsyła do sceny ukrzyżowania Chrystusa, wskazuje na ból matczyny wywołany śmiercią umiłowanego dziecka. Drugi zaś obraz - przebitego mieczem serca Maryi - poza wprowadzeniem kolejnej metafory wyrażającej cierpienie, odwołuje do wizerunków Matki Bożej Bolesnej, ilustrujących nie tylko Boskie, ale i narodowe motywacje cierpienia Maryi, spowodowane Jej duchowym, macierzyńskim orędownictwem za Polakami.

Konopnicka w Magnificat uwydatnia zatem heroizm i odpowiedzialność Matki Bożej, co wskazuje na przekroczenie pesymizmu ${ }^{37}$. Podczas gdy typową dla młodopolskiego dekadenta reakcją na doświadczenie nadmiaru cierpienia była deklaracja bierności i pesymizmu, a potem bunt, uczucie nienawiści czy nawet odrzucenie Stwórcy, mówiąca z wiersza Konopnickiej prezentuje postawę zgody, akceptacji męki przewidzianej w ciągu zdarzeń zainicjowanych w momencie Zwiastowania.

Nieco inny aspekt heroizmu Matki Bożej wyeksponował Leopold Staff w wierszu Zwiastowanie (z tomu Eabędź i lira, 1914). Utwór ten, podobnie jak Magnificat Konopnickiej, wychodzi poza problematykę Boskiego Zwiastowania. Autor antycypuje zdarzenia biblijne związane z męką i śmiercią Chrystusa. Przywołując obrazy Ostatniej Wieczerzy, chusty Weroniki, konania, konsekwentnie buduje uwznioślony wizerunek Matki Bożej Bolesnej. Oryginalność tekstu Staffa przejawia się nie tylko poprzez dowartościowanie postaci Maryi w kontekście Chrystusowej Pasji. Zwiastowanie to maryjny hymn dziękczynny, podzięka za poświęcenie i cierpienie. Efekt zaskoczenia przynosi jednocześnie zwrotka ostatnia: „Ave Maryja! Bądź pozdrowiona, / Że cała wieczność

$37 \quad$ Na heroizm Maryi w wierszu Botticelli. Magnificat Konopnickiej zwróciła też uwagę M. Jasińska, w przywoływanym już szkicu Matka Boska..., op. cit., s. 129. 
będzie Ci dłużna / Plonu z katuszy Twojego łona, / Bo najszczytniejszą z ofiar jest - próżna" ${ }^{38}$. Uwagę zwraca w niej przede wszystkim motyw próżnej ofiary, często eksponowany w liryce z przełomu wieków. Jego obecność w takich wierszach, jak Próżnia Stanisława Koraba-Brzozowskiego, Symbol Kazimierza Przerwy-Tetmajera czy Dies irae Jana Kasprowicza, ewokowała zazwyczaj pesymizm światopoglądowy ${ }^{39}$. Motyw próżnej ofiary obrazować też mógł młodopolską tendencję podważania dogmatów, prawd religii chrześcijańskiej, w tym przypadku dotyczących wewnętrznej jedności męki i Zmartwychwstania Chrystusa, jak również głębokiego, teologicznego sensu cierpienia i ofiary Maryi. Ulega on jednak w Zwiastowaniu Staffa rewaloryzacji, w porównaniu z dekadenckimi prezentacjami sfery sacrum - otrzymuje wykładnię heroiczną. Zmienia się tu także stosunek podmiotu mówiącego do religijnego adresata. Matka Boża jako ta, której cierpienie jest próżne, nie jest obciążona odpowiedzialnością za pomnażanie przynoszącego tylko cierpienie życia. Nie budzi też litości bądź współczucia (takie reakcje wywoływała najczęściej postać cierpiącego Chrystusa w poezji o zabarwieniu dekadenckim). Jest Ona raczej obiektem najwyższej czci, podziwu zarówno natury, jak i ludzkości. To cierpienie uwzniośla Maryję. Taki sposób Jej prezentacji, akcentujący i waloryzujący właśnie heroizm, współgra z ogólnymi tendencjami epoki, nastawionej, zwłaszcza przed pierwszą wojną światową oraz w jej trakcie na krzewienie zasad heroizmu, konieczności podjęcia ofiary ${ }^{40}$.

$$
* * *
$$

Przedstawione wyżej przykłady młodopolskich wierszy maryjnych warte są przypomnienia, ponownego przyjrzenia się ich warstwie artystycznej, językowej, a przede wszystkim przesłaniu i sugerowanym wartościom. Pochodzące z przełomu XIX i XX wieku utwory stanowić mogą inspirację również współcześnie. Większość z nich wyrasta bowiem z manifestowanej wielokrotnie miłości i czci dla Matki Bożej, szacunku wobec wartości religijnych, a przynajmniej estymy dla religijnego, podniosłego nastroju, ewokowanego przez maryjne nabożeństwa czy choćby odgłos kościelnych dzwonów na

38 L. Staff, Zwiastowanie, [w:] idem, Poezje zebrane, t. 1, Warszawa 1967, s. 1055.

39 Zob. W. Gutowski, Mit-Eros-Sacrum..., op. cit.

40 Por. tekst M. Podrazy-Kwiatkowskiej, Homo militans i homo faber. O nurcie heroicznym w literaturze Mtodej Polski, [w:] eadem, Somnambulicy-dekadenci - herosi. Studia i eseje o literaturze Mtodej Polski, Kraków 1985, s. 117-146. 
Anioł Pański. Inne natomiast młodopolskie utwory maryjne dyskretnie wskazują uniwersalne dylematy, problemy: egzystencjalne, społeczne, narodowe i religijne.

Słowa kluczowe: Matka Boża Dziewica, Zwiastowanie, motyw dziewictwa Maryi w literaturze, poezja Młodej Polski.

\section{Bibliografia:}

1. Filipkowska H., Poezja religijna Mtodej Polski, [w:] S. Sawicki, P. Nowaczyński (red.), Polska liryka religijna, Lublin 1983.

2. Grossek-Korycka M., Litania dziękczynna, przedr. [w:] Matka Boska w poezji polskiej. Antologia, t. 2, Lublin 1959.

3. Gutowski W., Mit-Eros - Sacrum. Sytuacje mtodopolskie, Bydgoszcz 1999.

4. Gutowski W., Wyobraźnia religijna czy religia wyobraźni? Dylemat (nie tylko) młodopolski, [w:] E. Paczoska, J. Sztachelska (red.), Literatura Młodej Polski. Między XIX a XX wiekiem, Białystok 1998.

5. Januszewicz M., Malowany dramat. O zwiazkach literatury $z$ malarstwem $w$ „Weselu” Stanistawa Wyspiańskiego, Zielona Góra 1994.

6. Jasińska M., Matka Boska w poezji poromantycznej (do r. 1918), [w:] Matka Boska w poezji polskiej: szkice o dziejach motywu, t. 1, oprac. M. Jasińska, Z. Jastrzębski i in., Lublin 1959.

7. Konopnicka M., Botticelli. Magnificat, [w:] M. Konopnicka, Poezje, wyd. zupełne, krytyczne, t. 4, oprac. J. Czubek, Warszawa 1915.

8. Kuryłowicz B., Semantyka nazw kwiatów w poezji Młodej Polski, Białystok 2012.

9. Lewandowski T., Mtodopolskie spotkania z modernizmem katolickim, [w:] S. Fita (red.), Problematyka religijna w literaturze pozytywizmu i Młodej Polski. Świadectwa poszukiwań, Lublin 1993.

10. Ławski J., Marie romantyków. Metafizyczne wizje kobiecości: Mickiewicz - Malczewski - Krasiński, Białystok 2003.

11. Niebios i ziemi królowa. Najświętsza Maryja Panna w poezji polskiej, zebrał i wstępem opatrzył E. Wolski, Włocławek 1914.

12. Nosek A., ,,Matko! Jak wiele masz twarzy?”. Młodopolskie wiersze o kobiecie $w$ roli matki i doświadczeniu macierzyństwa, Białystok 2014.

13. Nosek A., Matka Boża w kontekście młodopolskiej ludowości i witalizmu. „Panagia” Kazimiery Zawistowskiej, [w:] D. Kulesza, M. Lul, M. Sawicka (red.), Bóg artystów XX wieku, Białystok 2003.

14. Olech B., Harmonia, liryzm, trwoga. Studia o twórczości Bronistawy Ostrowskiej, Białystok 2012.

15. Ostrowska B., Przedwiośnie, [w:] B. Ostrowska, Poezje wybrane, oprac. A. Wydrycka, Kraków 1999.

16. Ostrowska B., Rozmyślania, [w:] B. Ostrowska, Utwory proza, Warszawa 1982. 
17. Podraza-Kwiatkowska M,. Pustka - otchtań - petnia. (Ze studiów nad mtodopolska symbolika inercji i odrodzenia), [w:] M. Podraza-Kwiatkowska (red.), Młodopolski świat wyobraźni. Studia i eseje, Kraków 1977.

18. Podraza-Kwiatkowska M., Homo militans i homo faber. O nurcie heroicznym w literaturze Mlodej Polski, [w:] M. Podraza-Kwiatkowska, Somnambulicydekadenci - herosi. Studia i eseje o literaturze Młodej Polski, Kraków 1985.

19. Podraza-Kwiatkowska M., Kompleks Parsifala. O mtodopolskim ideale czystości, [w:] M. Podraza-Kwiatkowska, Wolność i transcendencja, Kraków 2001

20. Ruffer J., Maryja Panna, [w:] J. Ruffer, Wybór poezji, wybór i oprac. M. Wyka, Kraków 1985.

21. Staff L., Zwiastowanie, [w:] L. Staff, Poezje zebrane, t. 1, Warszawa 1967.

22. Stala M., Pejzaż człowieka. Młodopolskie myśli i wyobrażenia o duszy, duchu $i$ ciele, Kraków 1994.

23. Trześniowski D., Biblijne twarze i maski. Młodopolski portret kobiety, [w:] E. Łoch (red.), Modernizm i feminizm. Postacie kobiece w literaturze polskiej i obcej, Lublin 2001.

24. Węgrzyniakowa A., Matka w poezji kobiet, [w:] G. Szewczyk (red.), Postać matki w niemieckiej i polskiej literaturze XIX $i$ XX wieku, Katowice 1995.

25. Wydrycka A., ,...Rymów gałazeczki skrzydlate...”. W świecie poetyckim Bronistawy Ostrowskiej, Białystok 1998.

26. Wydrycka A., Między bios a zoé. Poetycka antropologia w liryce Mtodej Polski. Interpretacje, Białystok 2012.

27. Wyspiański S., Akropolis, fragm. przedr. [w:] Matka Boska w poezji polskiej. Antologia, t. 2, Lublin 1959.

28. Zahorska A., Zwiastowanie, [w:] A. Zahorska, Dniom zmartwychwstania, Wilno 1921.

29. Zawistowska K., Przenajświętsza, [w:] K. Zawistowska, Utwory zebrane, Kraków 1982. 